Witold Brodziński

\title{
Refleksje o transformacji ustrojowej Węgier (państwo i naród jako podstawowe kategorie w „narodowym wyznaniu wiary”)
}

http://dx.doi.org/10.18778/8088-830-2.02

Rewolucje wschodnioeuropejskie końca lat osiemdziesiątych XX stulecia wyróżniało kilka fundamentalnych cech, spośród których podkreśliłbym: względnie pokojowy charakter przemian ustrojowych (z wyjątkiem Jugosławii i w jakimś stopniu Rumunii), szybkość, z jaką rewolucje zachodziły, a także swoisty efekt domina. Dlatego do symbolicznego napisu na transparencie w Pradze w grudniu 1989 r.: „Polska - 10 lat, Węgry - 10 miesięcy, NRD - 10 tygodni, Czechosłowacja - 10 dni", w kilka tygodni później można było dopisać „Rumunia - 10 godzin”.

Węgierską rewolucję 1989 r. określaną mianem „rewolucji negocjowanej” (styczeń-październik 1989) „zamyka” nowelizacja ustawy zasadniczej z sierpnia 1949 r. Nowela konstytucyjna z 18 października 1989 r. otworzyła zasadniczy etap zmian ustrojowych na Węgrzech. Wybory do samorządów lokalnych (jesień 1990) zakończyły podstawowe przekształcenia w strukturach władzy publicznej. Rozpoczął się wieloaspektowy proces kształtowania się demokratycznego, opartego na rządach prawa, państwa węgierskiego, czyli państwa, które przyjęło wartości charakterystyczne dla demokracji liberalnej. Dwie dekady później rewolucja „nad urnami" (wybory do Zgromadzenia Krajowego z 11 i 25 kwietnia 2010 r.) przyniosła wyraźne zwycięstwo partiom centroprawicowym: Węgierskiej Partii Obywatelskiej (FIDESZ) oraz Chrześcijańsko-Demokratycznej Partii Ludowej (NEPART). W pierwszą rocznicę zwycięstwa wyborczego parlament uchwalił Ustawę Zasadniczą Węgier (została podpisana przez prezydenta P. Schmitta 25 kwietnia 2011 r. i weszła w życie 1 stycznia 2012 r.).

${ }^{1}$ Analizę cech charakterystycznych rewolucyjnych przemian w państwach postkomunistycznych w Europie znaleźć można m.in. w opracowaniu S. Kotkin (współpraca J.T. Gross), Rok 1989. Koniec społeczeństwa nieobywatelskiego, Warszawa 2009, s. 7-176. 
W ustroju Węgier doszło do fundamentalnych zmian społeczno-politycznych, których przeprowadzenie przywódca Fideszu Viktor Orban zapowiedział już kilkanaście godzin po zwycięstwie wyborczym centroprawicy w kwietniu 2010 r. Nazajutrz po ogłoszeniu wyników wyborów parlamentarnych V. Orban oświadczył: „W niedzielę [tj. 25 kwietnia 2010 r. - W.B.] Węgrzy postanowili zburzyć dotychczasowy ustrój polityczno-gospodarczy i zbudować na jego miejsce nowy"2 2 .

Pod koniec 2011 r. (30 grudnia) Zgromadzenie Krajowe uchwaliło Postanowienia Przejściowe o przejściu od dyktatury komunistycznej do demokracji. Podstawowym z prawno-konstytucyjnego punktu widzenia przepisem „postanowień przejściowych” jest art. 1, w którym jest mowa o tzw. zaniechaniu ustawodawczym, które miało miejsce po 2 maja 1990 r. Chodzi o to, że ówczesny ustawodawca (Zgromadzenie Krajowe wybrane w wolnych, demokratycznych wyborach z 2 maja 1990 r., jak i kolejne legislatywy wybierane w latach 1994-2010) nie uchwalił postanowień rangi konstytucyjnej zrywających ciągłość uchwalonego przed 2 maja 1990 r. ustawodawstwa.

Nie od rzeczy będzie przypomnienie pewnego faktu, a mianowicie tego, że V. Orban był po raz pierwszy premierem w latach 1998-2002. W tym okresie ekipa V. Orbana przeprowadzała, jak twierdzą współpra10 cownicy premiera, zmiany precyzyjnie, wszystko badała i koordynowała, ale po czterech latach zorientowała się, jak wielu rzeczy nie zdążyła przeprowadzić. Teraz (po zwycięstwie wyborczym z 2010 r.) „Viktor postanowił wszystko zrobić tak szybko, jak się da" - opowiadał bliski współpracownik premiera Orbana ${ }^{3}$.

Ponieważ zmiany ustrojowe na Węgrzech trwają już niemal dekadę, a jak można przypuszczać z niemal stuprocentową pewnością wybory parlamentarne w przyszłym roku (2018) wygra Fidesz, można zapytać - czy po odrzuceniu mechanizmów demokracji liberalnej w 2010 r. Węgry zmierzają ku systemowi, którego podstawowy opis zamyka się w trzech słowach: "credere, obbedire, combattere"? Tego ostatniego zwrotu, czyli „combattere", użyłem świadomie i celowo, ponieważ od niemal 100 lat Węgrzy żyją w cieniu tzw. trianońskiej traumy. Sceptykom, którzy uznaja, że przywołanie formuły "combattere” jest zwykłym (propagandowym można by powiedzieć) nadużyciem, polecam uważną lekturę wielowąt-

${ }^{2}$ Zob. I. Janke, Napastnik. Opowieść o Viktorze Orbanie, Warszawa 2012, s. 235. O ideologii i zamierzeniach politycznych Fideszu zob. P. Lendvai, Hungary between Democracy and Autoritarism, London 2012. Ciekawą analizę tezy, że „wybory legitymizują przedstawicieli do sprawowania władzy w imieniu suwerena”, przeprowadziła A. Młynarska-Sobaczewska w monografii pt. Autorytet państwa. Legitymizacyjne znaczenie prawa w państwie transformacji ustrojowej, Torun 2010, s. 75 i n.

${ }^{3}$ I. Janke, Napastnik..., s. 235. 
kowej monografii P. Lendvai, Wegrzy. Tysiąc lat zwycięstw w kleskach ${ }^{4}$. Do niezmiernie rzadkich należy sytuacja, żeby uczony, który nota bene uznany został przez ekipę polityczną V. Orbana, niemal za personę non grata na Węgrzech, trudne zagadnienie nacjonalizmu węgierskiego przedstawił $\mathrm{w}$ tak obiektywny i zdystansowany od jakichkolwiek emocjonalnych reakcji sposób.

Skoro ekipa polityczna V. Orbana traktuje od niemal dekady mechanizmy liberalnej demokracji za coś bardzo szkodliwego dla przemian demokratycznych na Węgrzech po 1989 r., usprawiedliwione jest pytanie: czy mechanizmy demokracji liberalnej w państwie postkomunistycznym mogły mieć znaczącą siłę sprawczą? Na ile rzeczywista mogła być recepcja mechanizmów demokracji liberalnej po 1989 r. na Węgrzech, w państwie, które przez kilkadziesiąt lat XX stulecia doświadczyło autorytarnych rządów (1920-1944), następnie przez krótki, zarazem bardzo dramatyczny czas rządów faszystowskich (1944-1945), a po zakończeniu drugiej wojny światowej kilkudziesięcioletniego okresu dyktatury komunistycznej (1947-1989), dyktatury bardzo opresyjnej wobec społeczeństwa zwłaszcza w okresie 1948-1958?

Pytanie można i naturalnie należy odnieść do wszystkich państw postkomunistycznych w Europie Środkowo-Wschodniej. Czy po rewolucyjnych przemianach z okresu 1989-1990 istniały w którymkolwiek z państw tego regionu warunki do rzeczywistej recepcji, ukształtowanej po drugiej wojnie światowej na Zachodzie, ideologii liberalnej? Zdaniem J. Szackiego, autora fundamentalnej w tym temacie monografii Liberalizm po komunizmie, liberalizm w Europie Wschodniej pojawił się po 1989 r. przede wszystkim ,jjako wizja społeczeństwa, wyrastająca z protestu przeciwko istniejącemu stanowi rzeczy i pozbawiona $\mathrm{w}$ istocie zakorzenienia historycznego". Według niego, liberalizm miał swoją bazę stworzyć i po raz pierwszy w swojej historii musiał być „konstruktywistyczny, chociaż do jego trwałej natury należy niechęć do konstruktywizmu" ${ }^{\prime 5}$. Kraje postkomunistyczne (także Węgry) nie stały „przed perspektywą powrotu do zachodniej liberalnej demokracji, od której były dość beznadziejnie oddalone nie tylko pod panowaniem komunizmu, ale i wcześniej"6 .

Komunizm uczynił bowiem bardzo wiele nie tylko dla wyeliminowania idei liberalnych ze społecznego obiegu, miał również imponujące osiągnięcia $\mathrm{w}$ niszczeniu wszelkich ostoi niezależności jednostki od władzy państwowej. Chodzi nie tylko o niemal całkowite upaństwowienie gospodarki, lecz chodzi także o wszelkie próby, bardziej lub mniej

\footnotetext{
${ }^{4}$ P. Lendvai, Tysiac lat zwycięstw w klęskach, Kraków 2016, s. 541-563.

5 J. Szacki, Liberalizm po komunizmie, Kraków 1994, s. 257.

${ }^{6}$ Ibidem, s. 254.
} 
skuteczne, tzw. upaństwowienia świadomości, czyli zlikwidowanie rynku idei oraz zablokowanie większości kanałów komunikacji społecznej. Jednak zdaniem J. Szackiego, "zgeneralizowany etatyzm” odczuwany przez wiele jednostek jako dolegliwość miał także swoiste "uroki”: obywatel zwolniony był od odpowiedzialności za swój jednostkowy los oraz miał zapewnione pewne minimum bezpieczeństwa socjalnego ${ }^{7}$. Opór przeciwko systemowi komunistycznemu (NRD, Węgry, Czechosłowacja, Polska) w zasadzie nie miał nic wspólnego z ukształtowaną po drugiej wojnie światowej na Zachodzie Europy ideologią liberalną. Podstawową rolę w działaniach opozycji antykomunistycznej odgrywała obrona praw człowieka oraz organizacja społeczeństwa obywatelskiego, czyli formy zrzeszania się jednostek, formy pozwalającej na „ekspresję autentycznych potrzeb indywidualnych i zbiorowych" ${ }^{\prime 2}$.

Realistyczna co do perspektyw możliwości recepcji modelu liberalnej demokracji w państwach postkomunistycznych po 1989 r. analiza znakomitego socjologa nie wyklucza jednak (oczywiście mamy na myśli bardzo odległą perspektywę historyczną) trwałego zwrotu w państwach postkomunistycznych ku mechanizmom demokracji liberalnej. Natomiast organiczna, uwarunkowaną historycznie, a przede wszystkim mentalnie, niezdolność społeczeństw postkomunistycznych (Czechy, Polska, Słowacja,

12 Węgry) do recepcji zachodnioeuropejskiego modelu liberalnej demokracji zdaje się dostrzegać autor esejów Pomimo i wbrew. Eseje o Europie Środkowej. Znamienna, skłaniająca zarazem do krytycznej zadumy nad rzeczywistymi problemami ustrojowymi państw postkomunistycznych wydaje się być polemika T.G. Asha z poglądami węgierskiego filozofa G. Konrada, który w Antypolityce wprowadził jakiś czas temu (w latach osiemdziesiątych XX w.) kategorię „nowej tożsamości środkowoeuropejskiej”" . Zdaniem G. Konrada, państwa Europy Środkowej (oczywiście chodzi także, a może przede wszystkim, o Węgry) nie mogły zrealizować wariantu (ustrojowego) zachodniego, ponieważ po roku 1945 państwa środkowoeuropejskie znalazły się po raz kolejny w strefie hegemonii wschodniej, tym razem sowieto-rosyjskiej ${ }^{10}$.

Brytyjski badacz idei zauważył, że G. Konrad wykazał mitotwórcze skłonności, skoro każe przyjąć czytelnikom, że „wszystko, co było w istocie swej »środkowoeuropejskie«, zawsze było zachodnie, racjonalne, humanistyczne, demokratyczne, sceptyczne i tolerancyjne"11. A prze-

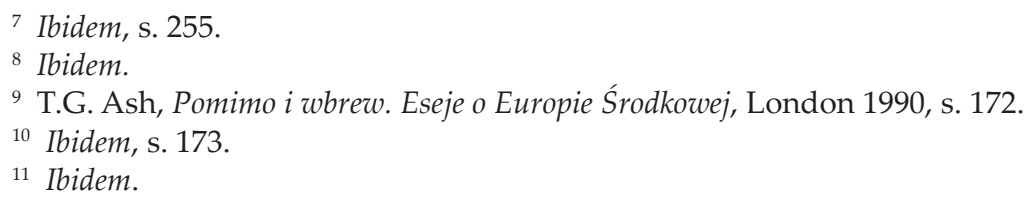

${ }^{11}$ Ibidem. 
cież „superbiurokratyczna supremacja państwa i formalizm prawny doprowadzony do absurdalnych (i niekiedy już nieludzkich) skrajności był przecież cechą szczególnie charakterystyczną dla Europy Środkowej już przed rokiem 1914"12.

Z pewnością uwaga zachodniego badacza idei dotyczy nie tylko samej Austrii (przed 1914 r.), ale w co najmniej identycznym stopniu Węgier. Na miejscu jest przywołanie wypowiedzi innego wybitnego myśliciela społecznego i politycznego, profesora uniwersytetu w Budapeszcie, I. Bibo. W znakomitym eseju Nędza małych państw wschodnioeuropejskich, przyjmując za punkt wyjścia rozważań losy powojennych (po 1914 r.) Węgier, przeprowadził wnikliwą analizę problemów regionu środkowoeuropejskiego (de facto chodzi o państwa współczesnego tzw. Wyszehradu). I. Bibo podjął próbę rozstrzygnięcia kluczowego dla tej części Europy, zarazem aktualnego zagadnienia granic demokracji, kwestii stosunku do mniejszości, wolności czy problemów nacjonalizmu ${ }^{13}$. Tak na marginesie odnotujmy, że I. Bibo mimo swej legendarnej wręcz postawy męża stanu w 1956 r. oraz represji, jakich doświadczył ze strony komunistycznego reżimu, nie został uznany przez żadną z obecnych po 1989 r. na węgierskiej scenie politycznej partii za swego patrona. Żadna z sił politycznych, obecnych na Węgrzech po 1989 r., nie odkryła w jego pismach jakichkolwiek przesłanek własnego programu politycznego ${ }^{14}$. I. Bibo zauważa, że na wzajemnych stosunkach narodów środkowoeuropejskich fatalnie zaciążyły przede wszystkim: zakłócenie $\mathrm{w}$ XX stuleciu terytorialnego statusu Europy Środkowej i Wschodniej oraz deformacja jej kultury politycznej. Pełna goryczy wydaje się jego, tragiczna wręcz w wydźwięku, konstatacja, że „życie polityczne w tej części Europy pełne jest małostkowych i nierozwiązywalnych sprzeczności terytorialnych i właściwie każdy tutejszy naród znajduje się w ciągłej kontrowersji ze swymi wszystkimi sąsiadami ${ }^{15}$.

Preambule (Narodowe wyznanie wiary) do konstytucji z kwietnia 2011 r. przypisać można szczególny charakter. Jej tekst zawiera istotne treści historyczne i ideologiczne. Jest katalogiem najbardziej istotnych wartości w życiu państwa i narodu oraz zakreśla perspektywy kształtowania ustroju społeczno-politycznego Węgier po 2010 r., czyli, przywołując wypowiedzi V. Orbana oraz najbliższych jego współpracowników,

12 Ibidem.

13 I. Bibo, Eseje polityczne, przeł. J. Snopek, Kraków 2012, s. 19.

14 Jak informuje J. Snopek - tłumacz Esejów politycznych, a zarazem autor znakomitego wstępu do nich - radykalnie skrócona wersja Wstępu (czyli wersja dość drastycznie ocenzurowana) ukazała się w przekładzie węgierskim w 2011 r. na łamach miesięcznika „Kortars” 2011, nr 12, zob. J. Snopek, Wstęp, [w:] I. Bibo, Eseje..., s. 5.

15 Ibidem, s. 63. 
„po odzyskaniu Węgier przez naród węgierski”. Postanowienia preambuły ponadto mają moc normatywna, czyli wyznaczają treść oraz zakres wykładni norm Ustawy Zasadniczej Węgier („,Przepisy Ustawy Zasadniczej należy interpretować zgodnie $\mathrm{z}$ ich celami, określonymi w narodowym wyznaniu wiary zawartym w Ustawie Zasadniczej oraz zdobyczami naszej historycznej konstytucji”, art. R.3; także art. 28: „W wykładni Ustawy Zasadniczej i ustaw należy mieć na względzie, iż służą one realizacji celów moralnych"). Ze względu na wymogi redakcyjne (objętość opracowania) poruszę tylko trzy bardzo istotne zagadnienia, które wybijają się w preambule na plan pierwszy.

Trauma trianońska (,,jedność naszego narodu, która w wichrach minionego stulecia rozerwana została na części"). Wiemy, że traktat pokojowy z Węgrami z czerwca w 1920 r. w Trianon odłączył od Węgier nie tylko ziemie zamieszkane przez ludność innojęzyczną lecz także rozległe terytoria węgierskie. Węgierska opinia publiczna po roku 1920 przypisywała rozbiór wielkich historycznych Węgier wyłącznie brutalnej przemocy zwycięzców. Nie dostrzegano żadnej różnicy między odłączeniem od Węgier (od ziem tzw. Korony św. Stefana) dojrzałych do tego terytoriów, zamieszkałych przez ludność obcojęzyczną, a bezprawnym $\mathrm{w}$ istocie rzeczy zaborem ziem zamieszkałych przez ludność węgierskojęzyczną. Od 14 niemal 100 lat Węgry nie zdołały oderwać się od obrazu wielkich historycznych Węgier (w preambule czytamy o szacunku do „zdobyczy naszej historycznej konstytucji oraz do Świętej Korony [podkr. - W.B.]), która ucieleśnia konstytucyjną ciągłość państwowości Węgier". Ustawa Zasadnicza z 2011 r. utwierdza współczesnych Węgrów w przekonaniu, że Europa dopuściła w $1920 \mathrm{r}$. wobec nich do bardzo ciężkiej niesprawiedliwości. Wypowiedzi niektórych polityków węgierskich (np. byłego ministra spraw zagranicznych J. Martonyi z 2014 r. o potrzebie przyznania autonomii dla ziem zamieszkałych przez tzw. Szeklerów) czy też działania Kościoła Reformowanego Węgier (proklamacja na Synodzie w Debrecenie w czerwcu 2014 r. powołania ponadnarodowej struktury, czyli Kościoła Reformowanego historycznych Węgier) są działaniami nie tylko przemyślanymi, ale także cieszą się pełnym poparciem władz publicznych.

Zdaniem I. Bibo, by nowoczesny rozwój danej wspólnoty narodowej był harmonijny i jednolity, ,jest właściwe tylko to, by sprawa wspólnoty i sprawa wolności stanowiły jedność" ${ }^{16}$. Ponieważ demokratyzm i nacjonalizm są ruchami o wspólnych korzeniach, to rozchwianie tego związku może prowadzić do ciężkich zakłóceń rozwojowych. Wydarzenia polityczne na Węgrzech w latach 1918-1919 potwierdzają tezę I. Bibo, „że upadek sił politycznych i społecznych uciskających lud w przeszłości

${ }^{16}$ Ibidem, s. 56 . 
Refleksje o transformacji ustrojowej Wegier...

oraz przyjęcie demokracji wraz z jej nawet skrajnymi konsekwencjami" może doprowadzić do katastrofy społeczno-politycznej ${ }^{17}$. Może powstać antydemokratyczny nacjonalizm, co potwierdziło życie polityczne na Węgrzech po objęciu władzy w 1920 r. przez regenta M. Horty’ego.

Oficjalna ideologia państwowa po 2010 r. też została oparta na fundamentach antydemokratycznego nacjonalizmu; mniej istotne jest, czy w ślad za premierem V. Orbanem powiemy o „demokracji suwerennej”, czy w nawiązaniu do ideologii autorytarnej będziemy mówić o „demokracji scentralizowanej". Te kwestie mają znaczenie drugorzędne. Najistotniejsze jest dominujące przekonanie twórców Ustawy Zasadniczej z 2011 r. o skrzywdzonym narodzie węgierskim. Przekonanie oparte niestety na różnorakich kłamstwach historycznych. Skoro czytamy w preambule o "nieludzkich zbrodniach popełnionych przeciwko narodowi węgierskiemu", to zastanawiające jest milczenie o zbrodniach popełnionych przez honwedów stojących u boku armii III Rzeszy, czy też o zbrodniach popełnionych wobec mniejszości narodowych zamieszkujących terytorium Węgier po 1940 r. po tzw. drugim arbitrażu wiedeńskim. Jako chrześcijanin celowo nie podejmuję rozważań o tym, że wspomniane kłamstwa zapisane w preambule poprzedza odwołanie się do transcendencji („Boże, błogosław Węgrów”).

W zakończeniu przywołam pierwszy z pięciu zasadniczych błędów metodologicznego nacjonalizmu (Węgry po 2010 r. są znakomitym przykładem państwa, przyjmującego nacjonalizm jako podstawę ustroju polityczno-społecznego). Zdaniem U. Becka, „W obliczu faktu, iż rządzenie w coraz większym stopniu dokonuje się w przestrzeniach wyzbytych granic, wielokrotnie już stawiane pod znakiem zapytania, nadal jednak charakterystyczne dla nauki o polityce polityki wewnętrznej od zagranicznej, rządzenia od stosunków międzynarodowych, stanie się ostatecznie anachronizmem"18. Dedykuję te słowa twórcy Momentum Mozgalom panu Andrasowi Fekete-Gyor, którego niezwykła wręcz energia oraz pasja społeczna sprawiły, że liczący raptem 140 członków ruch społeczny

${ }^{17}$ O przyczynach i następstwach podziałów społecznych na Węgrzech bardzo interesująco pisze P. Esterhazy w Harmonia caelistis, Warszawa 2007, z posłowiem tłumacza T. Worowskiej. Polecam zwłaszcza te partie tego swoistego traktatu napisanego przez potomka rodu Esterhazych, w których wyjaśnia on znaczenie podziałów w narodzie węgierskim na tzw. labanców oraz tzw. kuruców. Ten podział nadal funkcjonuje (chociaż nie $\mathrm{z}$ taką siłą jak w wiekach XVIII czy XIX także dzisiaj). Obecna ekipa polityczna wykorzystuje historyczne podziały, przeciwstawiając patriotyczną większość społeczeństwa (współcześni rodzimi „kurucowie”) elitom, zorientowanym na kosmopolityczny Zachód (współcześni rodzimi „labancowie”).

${ }_{18}$ U. Beck, Władza i przeciwwładza w epoce globalnej. Nowa ekonomia polityki światowej, Warszawa 2005, s. 77. 
(luty 2017) potrafił zebrać aż 266 tys. podpisów pod wnioskiem o referendum w sprawie rezygnacji Budapesztu $\mathrm{z}$ ubiegania się o organizację igrzysk olimpijskich w 2024 r. (17 lutego burmistrz Budapesztu I. Tarlos oficjalnie wycofał kandydaturę stolicy Węgier).

\section{Literatura}

Ash Tg., Pomimo i wbrew. Eseje o Europie Środkowej, London 1990.

Beck U., Władza i przeciwwładza w epoce globalnej. Nowa ekonomia polityki światowej, Warszawa 2005.

Bibo I., Eseje polityczne, przeł. J. Snopek, Kraków 2012.

Esterhazy P., Harmonia caelistis, Warszawa 2007.

Janke I., Napastnik. Opowieść o Wiktorze Orbanie, Warszawa 2012.

Kotkin S. (współpraca J.T. Gross), Rok 1989. Koniec społeczeństwa nieobywatelskiego, Warszawa 2009.

Lendvai P., Hungary beetween Democracy and Autoritarism, London 2012.

Lendvai P., Tysiąc lat zwycięstw w klęskach, Kraków 2016.

Młynarska-Sobaczewska A., Autorytet pastwa. Legitymizacyjne znaczenie prawa w państwie transformacji ustrojowej, Toruń 2010.

16 Snopek J., Wstęp, [w:] I. Bibo, Eseje polityczne, Kraków 2012.

Szacki J., Liberalizm po komunizmie, Kraków 1994. 